\title{
$\mathbb{O}_{2}-J e t$ を用いた $\mathbb{C S}_{9}$ Re 添加銀粉体表面の動的 $\mathbb{X P S}$ 測定 ${ }^{\dagger}$
}

\author{
葛蒲 明己・鈴木 英之・安孫子 勤 \\ 室蘭工業大学応用化学科 $\quad$ E050 室蘭市水元町 $27-1$
}

(1993 年 5 月 20 日受付, 1993 年 7 月 8 日掲載決定)

\section{Dynamic XPS Measurement of Cs and Re-Doped Silver Powder Surface Using $\mathbb{O}_{2}$-Jet}

\author{
Akimi Ayame, Hideyuki Suzuni and Tsutomu Aвıкo \\ Department of Applied Chemistry, Muroran Institute of Technology \\ Mizumoto, Muroran, Hokkaido 050
}

(Received May 20, 1993: Accepted July 8, 1993)

\begin{abstract}
Electric charges, surface concentrations, and the dynamic behaviours of $\mathrm{Cs}$, Re, and $\mathrm{O}$ on selfsupported disk surface of $\mathrm{Cs}$ and Re-doped silver powder during the operation of $\mathrm{O}_{2}$-Jet under UHV were examined using XPS. Pile-up and creep-in of doped elements, in analogy with $\mathrm{O}$, were observed with heating and cooling of the sample, respectively. A drastic shift of $\operatorname{Re} 4 \mathrm{f}_{7 / 2}$ spectrum of 46.7 $\left(\mathrm{Re}^{7+}\right)$ to $40.9 \mathrm{eV}\left(\mathrm{Re}^{0}\right)$ took place when the sample was heated at 110 to $210^{\circ} \mathrm{C}$, while $\mathrm{Cs} 3 \mathrm{~d}_{5 / 2}$ only lay in the range of $724.8 \sim 725.2 \mathrm{eV}$. Conspicuous transient responses to $\mathrm{O}_{2}$-Jet were exhibited by the sample heated at $210^{\circ} \mathrm{C}$; with increasing exposure time, the binding energy of $\operatorname{Re} 4 \mathrm{f}_{7 / 2}$ rapidly shifted from $40.9\left(\mathrm{Re}^{0}\right)$ to $45.3 \mathrm{eV}\left(\mathrm{Re}^{6+}\right)$, Cs $3 \mathrm{~d}_{5 / 2}$ did so from 725.2 to $724.6 \mathrm{eV}$, and $\mathrm{O}$ 1s gradually became a twin peak of 530.5 and $528.9 \mathrm{eV}$, of which composition of five core spectra obtained by deconvolution was varied vigorously. The $\mathrm{O}$ 1s core spectrum of $528.8 \mathrm{eV}$ assigned to oxydic oxygen and $\mathrm{CS}_{2} \mathrm{O}$ was found only during the operation of $\mathrm{O}_{2}-\mathrm{Jet}$ at $210^{\circ} \mathrm{C}$.
\end{abstract}

\section{1.はじめに}

表面分析技術の進歩は著しいが，真空の質の問題は今 なお改善されていない。加えて, 表面と気相（真空）と の圧力差が大きいため固体表面からは昇華, 蒸発, 脱離 が起り, 残留分子の表面への侵入, 衝突が起きている。 よって, 表面は真空の圧力と組成, バルク組成と濃度, 温度などを推進力とする平衡状態下にあって，ての状態 は常に変動していると考えるのが正しいであろう。金 属, 単結晶などでは $10^{-9} \mathrm{~Pa}$ 台での測定が可能である。 多結晶面からなる粉体試料一特に触媒のような異種元素 を含む活性表面の場合には，乙の真空下でも清浄表面は 得られ難い。乙れまでは，分析室外で処理した試料表面 を表面化学的任静的にとらえて解析されてきた。一方,

†第 12 回表面科学講演大会 (1992 年 12 月 15 17日) にて 発表
いずれかの条件を変化させるとき，それに対応した応答 （過渡現象）が表面特性に現れることあ容易に予想され る。

本研究では, これらのととに着目し, 表面構成元素 の動的酸化還元挙動, 酸素の吸着挙動をリアルタイムで in situ 測定する方法を試み, 限られた時間内でての平 衡状態を移動させるために，酸素ガスジェット $\left(\mathrm{O}_{2}-\mathrm{Jet}\right)$ と試料の背面加熱方式を併用することにした。試料に は, 酸化エチレン合成用触媒として開発された Cs-Re 同時添加銀触媒の表面 ${ }^{1}$ を用いた。

\section{2. 実験}

使用した装置は $512 \quad 1 \cdot \mathbf{s}^{-1}$ のイオンポンプを装着し た Perkin-Elmer ESCA 5100 で, X線源には $\mathrm{MgK} \alpha$ $(1253.6 \mathrm{eV}, 15 \mathrm{kV} \times 20 \mathrm{~mA})$ を用いた。本装置の運転条 件は Table 1 のとおりである。分析室にはリニアモー 
Table 1 Operation condition of ESCA 5100

\begin{tabular}{ll} 
X-ray source & $\mathrm{MgK} \alpha(1253.6 \mathrm{eV}, 15 \mathrm{keV} \times 20 \mathrm{~mA})$ \\
Take off angle & $54.7^{\circ}$ \\
Pass energy & $35.75 \mathrm{eV}$ \\
Scan speed & $50 \mathrm{~ms} / \mathrm{step}$ \\
Step width & $0.05 \mathrm{eV} / \mathrm{step}$ \\
Resolution & $F W H M$ of $\mathrm{Ag} 3 \mathrm{~d}_{5 / 2} 1.1 \mathrm{eV} \pm 0.1 \mathrm{eV}$ \\
Analytical area & $4 \times 10 \mathrm{~mm}^{2}$ \\
Work function & $4.6 \sim 4.7 \mathrm{eV}$ \\
Background pressure & $1 \sim 3 \times 10^{-8} \mathrm{~Pa}$ \\
Acquisition time & $3 \sim 5 \mathrm{~min} / \mathrm{element}$ \\
Sample temperature & room temp. $\sim 483 \mathrm{~K}$ \\
Operation pressure of $\mathrm{O}_{2}-\mathrm{Jet}$ & $5 \sim 6 \times 10^{-6} \mathrm{~Pa}$ \\
Calibration & $\mathrm{Cu} 2 \mathrm{p}_{3 / 2}=932.4 \mathrm{eV}, \mathrm{Cu} 3 \mathrm{p} 3 / 2=74.9 \mathrm{eV}$ \\
& $\mathrm{Au} 4 \mathrm{f}_{7 / 2}=83.8 \mathrm{eV}, \mathrm{C} 1 \mathrm{~s}=284.6 \mathrm{eV}$ \\
\hline
\end{tabular}

ション機構と超高真空流量制御バルブからなる $\mathrm{O}_{2}$ - Jet 装置を装着し， $1 \times 10^{-5} \mathrm{~Pa}$ 以下の酸素ガスに直接さらさ れている表面の in situ 測定が可能である。酸素圧は分 析室の圧力計でモニターした。加熱は八ロゲンランプに よる背面加熱方式で行い，表面温度は CA 熱電対を分 析面積の端に圧着させて測定した。 $\mathrm{Ar}^{+}$スパッタリング は Ar 圧 $1 \times 10^{-5} \mathrm{~Pa}, 3 \mathrm{kV}$ ，ラスター7で行った。ス ペクトルの deconvolution および原子組成の算出の場 合は shirley background 補正を行い，相対感度係数に は平均自由行程と断面積の差異を考慮して決定されてい る Perkin-Elmer Co. の推奖值を使用した ${ }^{2)}$ 。Cs, Re 添 加試料は, $\mathrm{AgNO}_{3}$ (関東化学, 99.9\%) 加ら得た $\mathrm{Ag}_{2} \mathrm{O}$ に所定量の $\mathrm{CsNO}_{3}$ (関東化学, 特級), $\mathrm{Re}_{2} \mathrm{O}_{7}$ ( $\mathrm{Nilaco}$ Co., $99.9 \%$ ）の水溶液を含浸, 蒸発乾固, 約 $60^{\circ} \mathrm{C}$ 水素 還元して作成した。ての 60〜150メッシュの軟らかい粉 体約 $200 \mathrm{mg}$ を $13 \mathrm{~mm} \phi$ ディスクに $600 \mathrm{~kg} \cdot \mathrm{cm}^{-2} \mathrm{G}$ で 加圧成型してミラー面を作り，400 ${ }^{\circ} \mathrm{C}, 3 \mathrm{~h}$ の水素還元 後乾燥窒素グローブボックス内で武料台に取付け分析室 に導入した（約 3 分間は大気に接触している）。なお， Cs, Re の添加量は Ag に対し 1000 ppm とした。 $\alpha$-ア ルミナ担体は光電子スペクトルを複雑にするので使用し ていない。Ar， $\mathrm{O}_{2}, \mathrm{H}_{2}$ は市販の最高純度品をそのまま 使用した。

\section{3. 実 験 結果}

繰返し実験を含めて本研究で用いたすべての試料で, かついかなる条件下でも $\quad \mathrm{Ag} 3 \mathrm{~d}_{5 / 2}$ の束縛エネルギー $(B E)$ は $368.1 \pm 0.1 \mathrm{eV}$, 半值幅 $(F W H M)$ は $1.1 \mathrm{eV}$ で不変であった。 $\mathrm{C} 1 \mathrm{~s} の B E$ あ $284.6 \pm 0.1 \mathrm{eV}$ にあっ た。粉体成型試料であるため, 酸素の存在しない表面は入 手できず，分析室導入時の表面原子組成比 $\mathrm{Cs} / \mathrm{Re} / \mathrm{O} / \mathrm{Ag}$ は11/0.2/23/66であった。Re に比べCs とOの表面濃 度が異常に大きい。得られた主要な $B E$ 值, $F W H M$
值，および表面原子組成は Table 2 亿，スペクトルの 形状変化は Fig. 1 に示した。

\section{$3.1 \mathrm{Ar}^{+}$スパッタリングによる清浄化}

$\operatorname{Re} 4 \mathrm{f}_{7 / 2}$ および $\mathrm{Cs}_{\mathrm{s}} 3 \mathrm{~d}_{5 / 2}$ の $B E$ はそれぞれ 46.8, $724.6 \mathrm{eV}$ で，5分間の軽い $\mathrm{Ar}^{+}$スパッタリング後む $B E$ 值に変化はなかった。 $\mathrm{O} 1 \mathrm{~s}$ の $B E$ む $532.3 \mathrm{eV}$ で 同様であった。乙の $\mathrm{Ar}^{+}$スパッタリングで Cs, Re, O の表面濃度は減少したが，○において顕著であった。

\section{$3.2 \mathrm{O}_{2}$-Jet 作動中の XPS 測定（室温表面）}

$\mathrm{Ar}^{+}$スパッタ後, $5 \sim 6 \times 10^{-6} \mathrm{~Pa}$ の $\mathrm{O}_{2}$ ガス吹き付け $\left(\mathrm{O}_{2}\right.$-Jet 作動) を室温で 105 分間行ったが, Cs $3 \mathrm{~d}_{5 / 2}$,

$\operatorname{Re} 4 \mathrm{f}_{7 / 2}$ の $B E$ 值はほとんど変動せず, $O 1 \mathrm{~s}$ が $0.3 \mathrm{eV}$ 低 $B E$ 側にシフトした。 $\mathrm{cs}, \mathrm{O}$ の表面濃度は若干の増 加傾向を示した。

\subsection{0 および $210^{\circ} \mathrm{C}$ 加熱表面}

Cs-Re-Ag 試料を $110,210^{\circ} \mathrm{C}$ に加熱しているときの 定常表面で得られたスペクトルをそれぞれ Fig. 1 の c, d で示した。 $110^{\circ} \mathrm{C}$ では, $\mathrm{Cs} 3 \mathrm{~d}_{5 / 2}$ は $725.0 \mathrm{eV}$ に, O $1 \mathrm{~s}$ 屯高 $B E$ 側が削がれて $531.7 \mathrm{eV}$ にシフトし, $\operatorname{Re} 4 \mathrm{f}_{7 / 2}$ の $B E$ は不動でスペクトル強度のみが著しく増大した。 さらに $210^{\circ} \mathrm{C}$ 亿昇温すると， $\operatorname{Re} 4 \mathrm{f}_{7 / 2}$ は 46.7 加ら 40.9 $\mathrm{eV}$ へ大幅にシフトし, 明確な化学状態変化を示した。 $\mathrm{Cs} 3 \mathrm{~d}_{5 / 2}, \mathrm{O} 1 \mathrm{~s}$ 屯それぞれ $725.2 ， 531.3 \mathrm{eV}$ 亿移動し た。なお，表面濃度においては Re が 2.5 倍に増大し， Cs の微増と○の減少が認められた。

\section{$3.4 \mathrm{O}_{2}$-Jet 作動中の XPS 測定 $\left(210^{\circ} \mathrm{C}\right.$ 加熱表面 $)$}

$210^{\circ} \mathrm{C}$ に加熱されている試料表面に $\mathrm{O}_{2}$-Jet を吹き付 けながら光電子スペクトルを経時的に測定した。作動前 は $3 \times 10^{-7} \mathrm{~Pa}$ であったととから, 試料表面への $\mathrm{O}_{2}$ 分子 の到達速度の平均増加分は $1.2 \times 10^{13} \mathrm{molecule} \cdot \mathrm{cm}^{-2} \cdot \mathrm{s}^{-1}$ で，測定中にこれだけの $\mathrm{O}_{2}$ 分子が新たに表面に降り注 いでいるととになる。Fig. 1 の e, f は O -Jet 作動開 始後 15〜25，90〜105 分に測定されたスペクトルであ 
Table 2 Binding energies $(B E)$, full width at half maximun ( $F W H M$ ), and surface atom concentration for silver powder containing $1000 \mathrm{ppm} \mathrm{Cs}$ and Re.

\begin{tabular}{|c|c|c|c|c|c|c|c|}
\hline \multirow[t]{2}{*}{ Sample condition } & \multicolumn{3}{|c|}{$B E$ and $(F W H M) / \mathrm{eV}$} & \multicolumn{4}{|c|}{ Atom concentration/\% } \\
\hline & Cs $3 d_{5 / 2}$ & $\operatorname{Re} 4 f_{7 / 2}$ & O1s & Cs & $\operatorname{Re}$ & $\mathrm{O}$ & $\mathrm{Ag}$ \\
\hline Just after sample introduction & $\begin{array}{r}724.6 \\
(2.0)\end{array}$ & $\begin{array}{l}46.6 \\
(1.5)\end{array}$ & $\begin{array}{r}532.3 \\
(3.3)\end{array}$ & 11 & 0.2 & 23 & 66 \\
\hline $\mathrm{Ar}^{+}$-sputtered for $5 \mathrm{~min}$ at r.t. & $\begin{array}{l}724.8 \\
(2.5)\end{array}$ & $\begin{array}{l}46.8 \\
(1.4)\end{array}$ & $\begin{array}{l}532.3 \\
(3.3)\end{array}$ & 10 & 0.2 & 18 & 72 \\
\hline Subjected to $\mathrm{O}_{2}$-Jet ${ }^{*}$ for $105 \mathrm{~min}$ at r.t. & $\begin{array}{c}724.8 \\
(2.0)\end{array}$ & $\begin{array}{l}46.9 \\
(-)\end{array}$ & $\begin{array}{r}532.0 \\
(3.9)\end{array}$ & 11 & 0.2 & 20 & 69 \\
\hline Heated at $110^{\circ} \mathrm{C}$ in $\mathrm{UHV}$ & $\begin{array}{r}725.0 \\
(1.9)\end{array}$ & $\begin{array}{l}46.7 \\
(1.8)\end{array}$ & $\begin{array}{r}531.7 \\
(2.9)\end{array}$ & 11 & 0.6 & 17 & 71 \\
\hline Heated at $210^{\circ} \mathrm{C}$ in $\mathrm{UHV}$ & $\begin{array}{r}725.2 \\
(2.0)\end{array}$ & $\begin{array}{l}40.9 \\
(2.2)\end{array}$ & $\begin{array}{r}531.3 \\
(3.0)\end{array}$ & 12 & 0.5 & 16 & 72 \\
\hline Subjected to $\mathrm{O}_{2}$-Jet*) for $15 \sim 25$, & 724.8 & 45.5 & 530.3 & 15 & 0.6 & 25 & 60 \\
\hline $30 \sim 45$ & 724.7 & 45.3 & $530.6,528.7$ & 14 & 0.7 & 26 & 59 \\
\hline $60 \sim 75$ & 724.6 & 45.2 & $530.5,528,9$ & 14 & 0.7 & 26 & 59 \\
\hline and $90 \sim 105 \mathrm{~min}$ at $210^{\circ} \mathrm{C}$ & $\begin{array}{r}724.6 \\
(2.2)\end{array}$ & $\begin{array}{l}45.3 \\
(2.1)\end{array}$ & $\begin{array}{c}530.5,528,9 \\
(4.2)\end{array}$ & 14 & 0.8 & 27 & 58 \\
\hline Cooled to r.t. in UHV & $\begin{array}{r}724.6 \\
(1.8)\end{array}$ & $\begin{array}{l}46.6 \\
(2.0)\end{array}$ & $\begin{array}{c}531.3,529.1 \\
(4.4)\end{array}$ & 8 & 0.3 & 15 & 77 \\
\hline $\begin{array}{l}\text { Cooled to r.t. in UHV after exposure } \\
\text { to } 133 \mathrm{~Pa} \mathrm{O}_{2} \text { for } 60 \mathrm{~min} \text { at } 210^{\circ} \mathrm{C}\end{array}$ & $\begin{array}{r}724.4 \\
(2.0)\end{array}$ & $\begin{array}{l}46.3 \\
(1.7)\end{array}$ & $\begin{array}{r}531.5 \\
(2.6)\end{array}$ & 12 & 0.3 & 21 & 67 \\
\hline
\end{tabular}

*) $\mathrm{O}_{2}$-Jet was operated at $5 \sim 6 \times 10^{-6} \mathrm{~Pa}$ of oxygen gas.
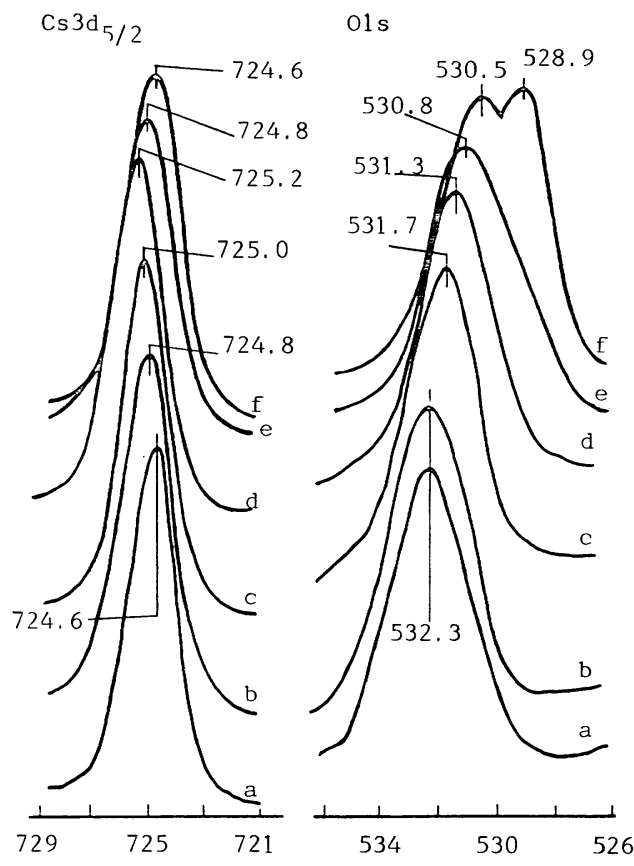

Binding energy / eV

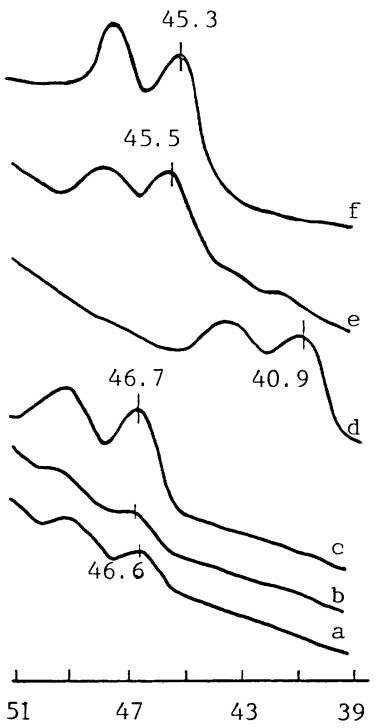

$\operatorname{Re} 4 f$

a : Just after sample introduction,

b : $\mathrm{Ar}^{+}$-sputtered for 5 $\min$ at r.t.,

c : Heated at $110^{\circ} \mathrm{C}$ in UHV,

d : Heated at $210^{\circ} \mathrm{C}$ in UHV,

e : Subjected to $\mathrm{O}_{2}$-Jet for $15 \sim 25 \mathrm{~min}$ at 210 ${ }^{\circ} \mathrm{C}$,

f : Subjected to $\mathrm{O}_{2}$-Jet for $90 \sim 150 \mathrm{~min}$ at $210^{\circ} \mathrm{C}$.

Fig. 1 Variations in $\mathrm{Cs}_{\mathrm{s}} 3 \mathrm{~d}_{5 / 2}, \mathrm{O} 1 \mathrm{~s}$, and Re $4 \mathrm{f}$ spectra for $(\mathrm{Cs}+\mathrm{Re})$-doped silver powder disk on successive treatments (1000 ppm of each element referred to silver). 
り，興味のある動的挙動が観測されている。Cs $3 \mathrm{~d}_{5 / 2}$ の $B E$ は直ちに $724.8 \mathrm{eV}$ 亿，その後 $724.6 \mathrm{eV}$ までシフ 卜した。同時に $\operatorname{Re} 4 \mathrm{f}_{7 / 2}$ は $40.9 \mathrm{eV}$ から $45.6 \mathrm{eV}$ に 大きくシフト (41〜 $44 \mathrm{eV}$ の部分にトレース程度のシグ ナルが見られた）し，その後強度の増大と共に $45.3 \mathrm{eV}$ まで移動した。てれらと連動して O 1 s スペクトルの低 $B E$ 倒が膨らみ始め, 30 分後に $528.9 \mathrm{eV}$ のピークが出 現した。 $531.3 \mathrm{eV}$ のピークは徐々に $530.5 \mathrm{eV}$ まで移 動し, 105 分後にはこれらは双頭ピークを形成した。 $\mathrm{O}_{2}-$ Jet 作動とと屯に Cs, Re, O の表面濃度は增加し始め, ○ の増加率は $69 \%$ に及んだ。

\section{$3.50_{2}$-Jet 作動後の UHV 下での降温}

$210^{\circ} \mathrm{C} \mathrm{O}_{2}$-Jet 作動 105 分後, 直ちに室温まで降温し た表面の分析結果によると，Cs，Re，O の表面濃度は 著しい減少を見せ， $\operatorname{Re} 4 \mathrm{f}_{7 / 2}$ の $B E$ が 45.3 から 46.6 $\mathrm{eV}$ にシフトした。O $1 \mathrm{~s}$ スペクトルは 531.3 と 529.1 $\mathrm{eV}$ のダブレットとなり, 前者と後者のピーク強度比は おおよそ 3 対 4 となった。

\section{$3.6210^{\circ} \mathrm{C}, 133 \mathrm{~Pa}-\mathrm{O}_{2}$ への静的暴露}

よく酸化された表面の状態を知る目的で, 予備室内に 移し，133 $\mathrm{Pa}$ の $\mathrm{O}_{2}$ ガスに $210^{\circ} \mathrm{C} ， 3$ 時間さらした試 料を, 冷却と同時に再び分析室に導入して室温で測定し た。双頭ピークをむつ O 1 $\mathrm{s}$ スペクトルは $531.5 \mathrm{eV}$ の 単一ピークとなり, Cs $3 \mathrm{~d}_{5 / 2}$ と $\operatorname{Re} 4 \mathrm{f}_{7 / 2}$ の $B E$ 值はそ れぞれ $0.2,0.3 \mathrm{eV}$ 低 $B E$ 侧に移動した。表面原子組 成比では Cs と O 亿増加が認められた。

\section{4. 考察}

\section{$4.1 \mathrm{Cs} 3 \mathrm{~d}_{5 / 2}$ スペクトルの帰属}

$\mathrm{C}_{\mathrm{s}_{2} \mathrm{O}}$ 結晶塊（キシダ化学，99\%）をデシケータ中で 大気に曝気し, 十分酸化させて $\mathrm{CsO}_{2}$ (黄色) が生成し た表面を分析した。Cs $3 \mathrm{~d}_{5 / 2}$ は $723.9 \mathrm{eV}, \mathrm{O} 1 \mathrm{~s}$ は $530.1 \mathrm{eV}$ の $B E$ を示し, Cs のオージェパラメーター は $1293.1 \mathrm{eV}$ で Briggs と Seah の推奨值 ${ }^{3)}$ と一致し た。表面を $\mathrm{Ar}^{+}$スパッタリングすると前者は 723.7, 後者は $528.3 \mathrm{eV}$ にショルダーをむつ $529.7 \mathrm{eV}$ のスペ クトルとなった。再び酸化すると, スパッタ前のスペク トルを再現した。 $\mathrm{CsO}_{2}$ と $\mathrm{Cs}_{2} \mathrm{O}$ の $\mathrm{Cs}_{3} 3 \mathrm{~d}_{5 / 2}$ の $B E$ に は $0.2 \mathrm{eV}$ 以下の差しかなく, おの㧍のに帰属するのは 難しい。な扔，てのときの $\mathrm{O} 1 \mathrm{~s}$ スペクトルの deconvolution の結果, $\mathrm{C}_{2} \mathrm{O}$ の O $1 \mathrm{~s}$ として $528.2 \mathrm{eV}$ を得 だ)。本実験では, 最も還元性雾囲気下にある表面の $\mathrm{Cs} 3 \mathrm{~d}_{5 / 2}$ は $725.2 \mathrm{eV}$ で，酸化すると $724.4 \mathrm{eV}$ までシ フトした (Table 2)。Ayyoob らは Ag 蒸着膜上の Cs の $726.4 \mathrm{eV}$ の Cs $3 \mathrm{~d}_{5 / 2}$ は $500 \mathrm{~L}$ の酸素吸着で 723.7 $\mathrm{eV}$ にシフトしたと報告している5)。金属 $\mathrm{Cs}, \mathrm{CsX}(\mathrm{X}=$
$\mathrm{F}, \mathrm{Cl}, \mathrm{Br})$ の $\mathrm{Cs} 3 \mathrm{~d}_{5 / 2}$ としてそれぞれ 726.0〜 726.4 $\mathrm{eV}, 723.4 \sim 723.8 \mathrm{eV}$ が報告されている2》。また, 最す 酸化された $500 \mathrm{ppm} \mathrm{Cs}$ 添加 $\mathrm{Ag}$ 試料上では $723.9 \mathrm{eV}$ が得られている4。以上のととから，Cs 添加および (Cs $+\mathrm{Re}$ ) 添加 $\mathrm{Ag}$ 試料の $\mathrm{Cs}_{\mathrm{s}}$ は $723.9<\mathrm{Cs}_{3} 3 \mathrm{~d}_{5 / 2}<$ $726.4 \mathrm{eV}$ の $B E$ をむつ $\mathrm{Cs}^{\delta+}(1>\delta>0 ; \delta$ が大である ほど $B E$ は低い）の状態にあって，Cs を取り囲む酸素 原子数（配位数）に依存して $\delta$ は変化していると考えら れる。

\section{$4.2 \operatorname{Re} 4 \mathrm{f}_{7 / 2}$ スペクトルの帰属}

$\mathrm{Re}_{2} \mathrm{O}_{7}$ (Koch Chem. Co., 99.9\%) の $\mathrm{Re} 4 \mathrm{f}_{7 / 2}$, O $1 \mathrm{~s}$ はそれぞれ 46.1，531.5 eV，Re-ribbon (Koch Chem. Co., 99.97\%) の $\operatorname{Re} 4 \mathrm{f}_{7 / 2}$ は $40.1 \mathrm{eV}$ (吸着酸素の $\mathrm{O} 1 \mathrm{~s}$ は $532.6 \mathrm{eV})$ であった。また, $\mathrm{Re}_{2} \mathrm{O}_{7}$ と $\mathrm{Re} 一$ powder (Koch Light Ltd., 99.95\%) のほぼ等モルの 混合物を封管中, $300^{\circ} \mathrm{C}$, 一昼夜焼成した。乙のとき,

$$
\mathrm{Re}_{2} \mathrm{O}_{7}+\mathrm{Re} \rightleftharpoons 2 \mathrm{ReO}_{2}+\mathrm{ReO}_{3}
$$

の反応が起り ${ }^{6)}$ ，一部未反応の $\mathrm{Re}_{2} \mathrm{O}_{7}$ が残る。得られた これらの混合物の $\operatorname{Re} 4 \mathrm{f}_{7 / 2}$ スペクトルを測定し, 上記 の $B E$ 值を参考にピーク分割し, $\mathrm{Re}^{6+}, \mathrm{Re}^{4+}$ 酸化物の $\operatorname{Re} 4 \mathrm{f}_{7 / 2}$ の $B E$ 值の決定を試みた (Fig. 2)。得られた 結果を文献值 ${ }^{7 \sim 11}$ と比較して Table 3 亿記載した。 $\mathrm{Re}^{7+}, \mathrm{Re}^{6+}, \mathrm{Re}^{4+}$ 亿対応する $\mathrm{O} 1 \mathrm{~s}$ としてはそれぞれ 531.5〜 531.9，530.7，529.3 eV が得られている。よっ て, 本研究で得られた 46.3〜46.9，44.7〜45.7，40.4〜 $40.9 \mathrm{eV}$ の各 $B E$ 值はそれぞれ $\mathrm{Re}^{7+}, \mathrm{Re}^{6+}, \mathrm{Re}^{0}$ に州 属できる。 $\mathrm{Ag}$ 中の $\operatorname{Re} 4 \mathrm{f}_{7 / 2}$ の $B E$ 值が価数に関係な く金属, 金属酸化物に比べて $0.2 \sim 0.8 \mathrm{eV}$ 高 $B E$ 側に 現れる理由は, 吸着酸素電子供与している $\mathrm{Ag}$ 原子へ の $\operatorname{Re}$ 最外殸電子の流れ込みと過剩酸素に囲まれること

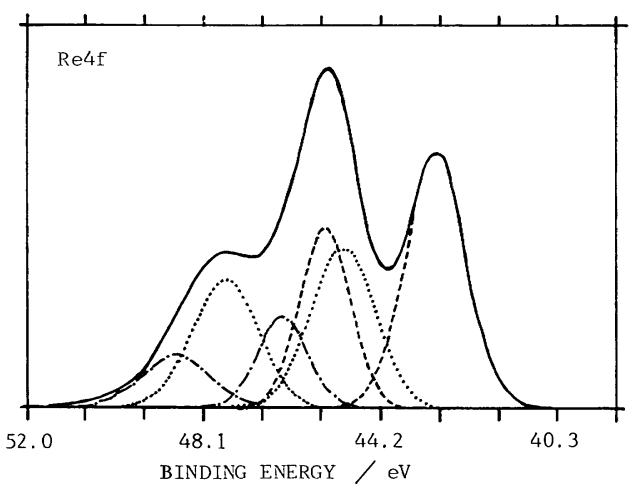

Fig. 2 Re $4 \mathrm{f}$ spectrum measured on the mixture powder of $\mathrm{ReO}_{2}, \mathrm{ReO}_{3}$, and $\mathrm{Re}_{2} \mathrm{O}_{7}$ and the deconvoluted core spectra.

- Original $\operatorname{Re} 4 \mathrm{f}$ spectrum, ---- $: \operatorname{Re}^{4+}$, …: $\operatorname{Re}^{6+},-\cdot-\cdot-: \operatorname{Re}^{7+}$. 
Table 3 Assignment of $\operatorname{Re} 4 \mathrm{f}_{7 / 2}$

\begin{tabular}{|c|c|c|c|c|c|}
\hline $\operatorname{Re}^{0}$ & $\mathrm{Re}^{3+}$ & $\mathrm{Re}^{4+}$ & $\operatorname{Re}^{6+}$ & $\operatorname{Re}^{7+}$ & Remarks \\
\hline 40.1 & - & 43.0 & 45.0 & $46.1 \sim 46.4$ & This work \\
\hline - & - & 43.9 & - & 一 & Leigh and Bremser ${ }^{7)}$ (1972) \\
\hline - & - & 44.1 & - & - & Cox and Hercules ${ }^{8)}$ (1972) \\
\hline 40.6 & - & 43.2 & 44.3 & 46.0 & Shpiro et al. ${ }^{9)}$ (1978) \\
\hline 40.1 & - & - & - & 45.9 & Perkin-Elmer Hand Book (1992) ${ }^{2)}$ \\
\hline 40.7 & - & 42.5 & 44.5 & 46.2 & Cimino et al. ${ }^{10)}(1980)$ \\
\hline 41.1 & 42.1 & 43.4 & 45.2 & 46.4 & Komiyama et al. ${ }^{11)}$ (1983) \\
\hline
\end{tabular}

による Re の電子密度に起因していると思われる。

\section{$4.301 \mathrm{~s}$ スペクトルの帰属}

$\mathrm{O} 1 \mathrm{~s}$ スペクトルはいずれの試料でも 2.6 から $4.4 \mathrm{eV}$ の $F W H M$ を屯ち, 単一化学種には帰属できない。前
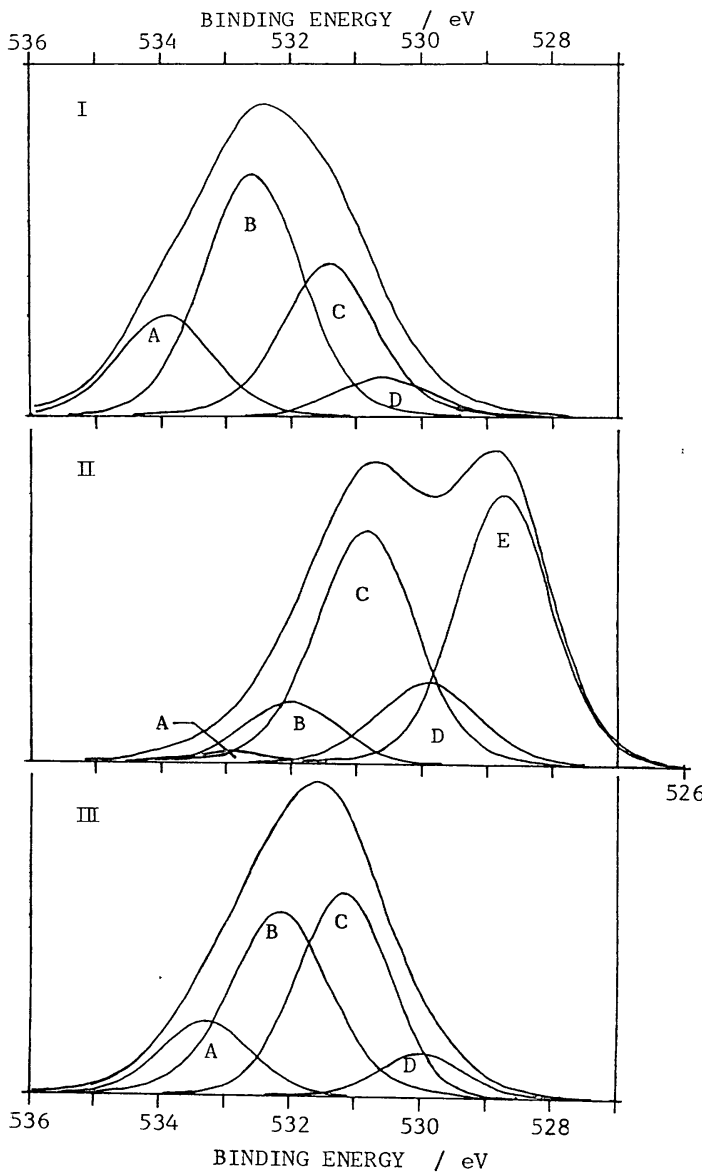

Fig. 3 Three examples for the deconvolution of $\mathrm{O} 1 \mathrm{~s}$ peak into five core spectra.

I : O $1 \mathrm{~s}$ spectrum after $\mathrm{Ar}^{+}-$sputtering for 5 min at r.t.

II : Subjected to $\mathrm{O}_{2}$-Jet for $90 \sim 105 \mathrm{~min}$ at $210^{\circ} \mathrm{C}$

III : After exposure to $133 \mathrm{~Pa} \mathrm{O}_{2}$ for $60 \mathrm{~min}$ at $210^{\circ} \mathrm{C}$ in a pretreatment chamber (measured at r.t.).
報4)に扔いて，Ag 上の吸着種に関する多くの文献値か ら 5 種類の酸素種が推定され，乙れらに基づく $\mathrm{O} 1 \mathrm{~s}$ ス ペクトルの deconvolution が良好な結果を与えたとと から，こてでも同様の解析を試みた。Gauss-Lorentz 関数の Gauss 関数比率を $80 \%$ 以上として，5個のコア スペクトルに分割した数例を Fig. 3 亿示した。本研究 で得られた各コアスペクトルの $B E$ 值, $F W H M$ 值は つぎの範囲内にあった。

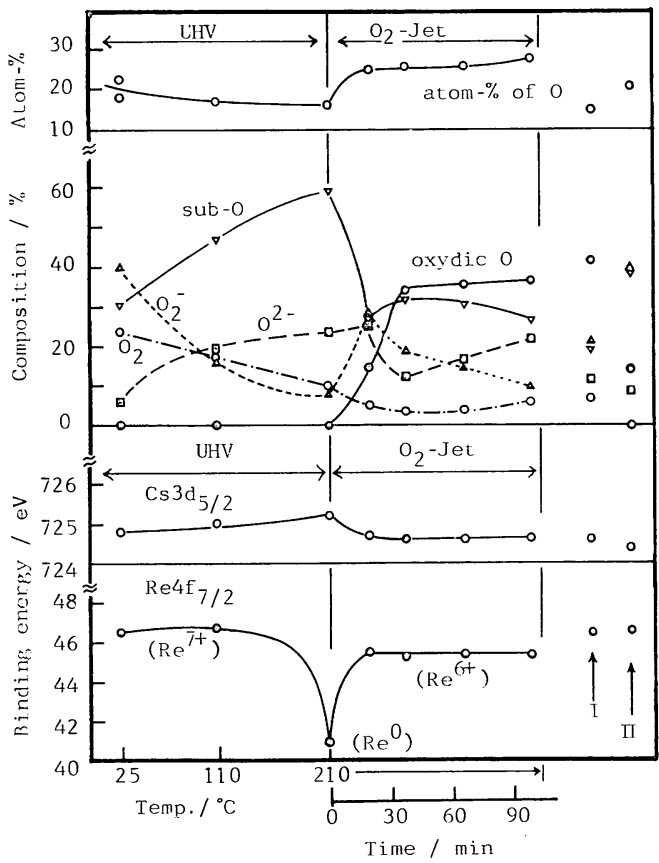

Fig. 4 Variations in binding energies of $\mathrm{Cs}_{\mathrm{S}} 3 \mathrm{~d}_{5 / 2}$ and $\operatorname{Re} 4 \mathrm{f}_{7 / 2}$, atom concentration of $\mathrm{O}$, and the composition of five core spectra of O $1 \mathrm{~s}$ with increasing sample temperature and exposure time to $\mathrm{O}_{2}-\mathrm{Jet}$ at $210^{\circ} \mathrm{C}$.

Symbol of $\mathrm{O}_{2}, \mathrm{O}_{2}{ }^{-}$, sub-O, $\mathrm{O}^{2-}$, and oxydic $\mathrm{O}$ in figure correspond to the core specturm $A$, $B, C, D$, and $E$, respectively. I and II show the data obtained on the sample cooled to r.t. after exposure to $\mathrm{O}_{2}-\mathrm{Jet}$ for $110 \mathrm{~min}$ at $210^{\circ} \mathrm{C}$ and to $133 \mathrm{~Pa} \mathrm{O}_{2}$ for $60 \mathrm{~min}$ at $210^{\circ} \mathrm{C}$ in a pretreatment chamber, respectively. 
A $533.1 \sim 533.6 \mathrm{eV} ; 1.6 \sim 1.8 \mathrm{eV}$,

$B \quad 531.7 \sim 532.6 \mathrm{eV} ; 1.6 \sim 1.8 \mathrm{eV}$,

C $530.4 \sim 531.4 \mathrm{eV} ; 1.7 \sim 1.8 \mathrm{eV}$,

D $529.5 \sim 530.6 \mathrm{eV} ; 1.7 \sim 1.9 \mathrm{eV}$,

E $\quad 528.1 \sim 528.8 \mathrm{eV} ; 1.7 \mathrm{eV}$.

前 4 者はそれぞれ $\mathrm{Ag}$ 上の吸着酸素分子 $\left(\mathrm{O}_{2}\right)_{\mathrm{ads}}$, 吸 着酸素分子 $\left(\mathrm{O}_{2}^{-}\right)_{\mathrm{ads}}$, サブサーフェス酸素原子 $\left(\mathrm{O}^{2-}\right)_{\mathrm{sub}}$, 吸着酸素原子 $\left(\mathrm{O}^{2-}\right)_{\mathrm{ads}}$ に対応している4)。5番目のコア スペクトル $E$ は $210^{\circ} \mathrm{C}, \mathrm{O}_{2}-\mathrm{Jet}$ 作動時に現れ, $\mathrm{Ag}$ 酸 化物酸素 $\left(\mathrm{O}^{2-}\right)_{\mathrm{ox}}$ の 528.8 529.3 $\mathrm{eV}^{4)}$ よりも若干低い $B E$ 值をむつ。4.1 節の結果によれば, $\mathrm{Cs}_{2} \mathrm{O}$ の酸素 $(528.2 \mathrm{eV})$ の寄与が働いていると考えられる。Table 2 の原子組成比から，Cs は 14 atom\% で $\mathrm{Cs}_{2} \mathrm{O}$ のOは約 7 atom\% と見積むられる。Fig. 4 から $E$ 種は全酸素 (27 atom\%) の約 35\%，すなわち，9.5 atom\% が存在 する。 $\mathrm{Cs}_{2} \mathrm{O}$ の $\mathrm{O}$ はての約 $70 \%$ に相当している。残る $30 \%$ の O C $\mathrm{s}, \mathrm{Re}, \mathrm{Ag}$ との間で特異的なマトリック スを作って存在していると思われる。一方，コアスペク トル $A$ は $\mathrm{O} 1 \mathrm{~s} 533.9 \mathrm{eV}$ の $B E$ をあつ凝集酸素分

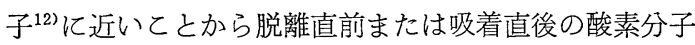
に起因する物理吸着様（短寿命）のあのと考えられる。

\section{4 加熱中, $\mathrm{O}_{2}$-Jet 作動中の動的挙動}

室温での $\mathrm{O}_{2}$-Jet 作動では表面酸素種間のダイナミッ クな表面状態変化を観測するには至らなかった。さらに 高い酸素圧が必要と思われる。一方，UHV 下での試料 背面加熱によって $110,210^{\circ} \mathrm{C}$ に保ち，定常的な表面状 態を測定した結果が Table 2, Fig. 1, Fig. 4 亿示して ある。表面濃度では $\mathrm{Cs}$ は微増だが, $\mathrm{Re}$ は $110^{\circ} \mathrm{C}$ で著 しく増大している。このときの $\operatorname{Re}$ は +7 価である。 $\mathrm{Re}_{2} \mathrm{O}_{7}$ は $\mathrm{Re}$ 酸化物中最む安定な酸化物であるが, 揮発 性で沸点は $362.4^{\circ} \mathrm{C}$ で, UHV 下ではさらに低下する。 よって, $\mathrm{Re}_{2} \mathrm{O}_{7}$ の昇華とバルクからの $\mathrm{Re}^{7+}$ の表面への 熱拡散移動 (pile-up) が起きていると解釈できる。また， 脱離による表面酸素量の減少があり, $\mathrm{Re}_{2} \mathrm{O}_{7}$ の $\mathrm{O} 1 \mathrm{~s}$ と 重なるコアスペクトル $B$ の比率は昇温ととむに急速に小

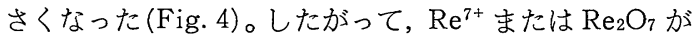
表面に浮き出て, 同時に $\operatorname{Re}^{7+}$ から $\operatorname{Re}^{0}$ への還元が
】起きていると考えられる。Cs と Cs 酸化物屯蒸気圧 の高い物質で, $\mathrm{Cs} 3 \mathrm{~d}_{5 / 2}$ の $B E$ 值を見る限り，同様の 現象が起きているものと考えられる。

$210^{\circ} \mathrm{C}$ での $\mathrm{O}_{2}$-Jet 作動中には，さらにダイナミック な化学状態変化の態様が入手できた。 $\mathrm{Re} は \mathrm{Re}^{0}$ から $45.3 \mathrm{eV}$ の $\mathrm{Re}^{6+}$ に, Cs は 725.2 から $724.6 \mathrm{eV}$ の 状態に酸化され，O $1 \mathrm{~s}$ スペクトルは約 $1 \mathrm{eV}$ 低 $B E$ 側 に移動して $528.9 \mathrm{eV}$ のピークが出現している。Fig. 4

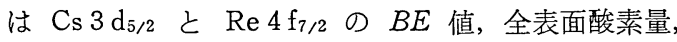
および O $1 \mathrm{~s}$ スペクトルの deconvolution で得られた 表面酸素種 $A \sim E$ の組成比の経時変化を示したあので ある。コアスペクトルEの酸素種は皆無の状態から $\mathrm{O}_{2}$ Jet 作動後急速に生成し始め, 30 分後には3 4\% 亿達し, その後む漸増した。 $\mathrm{O}_{2}$-Jet 作動前の主酸素種 $C$ （サブ サーフェス酸素) は動作直後に半減し，その後微増した。 吸着酸素分子 $A$ は減少したままで, $B\left(\mathrm{O}_{2}{ }^{-}\right)$は一度 3 倍 に急増したのち漸減した。吸着酸素原子 $D\left(\mathrm{O}^{-2}\right)$ は 15 分 後から半減し，30 分以降は増加に転じた。全表面酸素量 は Langmuir 型で増加し，作動前の 1.6 倍強となり，同 時に $\mathrm{Cs}, \operatorname{Re}$ あ若干表面に pile-upしている。これらの 挙動は $\operatorname{Re}$ 加ら $\operatorname{Re}^{6+}$ への酸化, $\mathrm{Cs}$ 酸化物の生成と密接 な関係にある。束縛エネルギー值としては，酸素種 $E$ は $\mathrm{Cs}_{2} \mathrm{O}$ の O $1 \mathrm{~s} 528.2 \mathrm{eV}, B$ は $\mathrm{Re}_{2} \mathrm{O}_{7}$ の 531.5 531.9 $\mathrm{eV}$ ，サブサーフェス酸素 $C$ は $\mathrm{ReO}_{3}$ の $530.7 \mathrm{eV}$, 酸 素種 $D$ は $\mathrm{ReO}_{2}$ の $529.0 \mathrm{eV}$ および $\mathrm{CsO}_{2}$ の 530.1 $\mathrm{eV}$ の O 1s スペクトルとそれぞれ重なっている。しか し, $\operatorname{Re}^{4+}$ と $\mathrm{Re}^{7+}$ は観測されず，O1s スペクトルは主 に $E$ と $C$ 種の双頭ピークであることから， Cs は $\mathrm{Cs}_{2} \mathrm{O}$, $\mathrm{Re}$ は $\mathrm{ReO}_{3}$, または $\mathrm{ReO}_{3}$ と $\mathrm{Cs}_{2} \mathrm{O}$ の一部とで複合 酸化物 $\mathrm{Cs}_{2} \mathrm{ReO}_{4}$ を形成して存在し, 残る酸素は主に $\left(\mathrm{O}^{2-}\right)_{\text {sub }}$ であると考えるととができる。

以上のように, 表面酸素種 $A \sim E$ は $\mathrm{Ag}$ および共存 する $\mathrm{Cs}, \operatorname{Re}$ との間で起こる複雑な相互作用の総合され た一つの結果として存在する。Cs, Re の酸化還元と表 面全酸素量の増減が連動していることから， $\mathrm{O}_{2}$-Jet 作 動時のコアスペクトルの組成変化はつぎの多段化学平衡 が右側へ移動する速度に対応しており，

$$
\mathrm{O}_{2}(\mathrm{~g}) \rightleftharpoons\left(\mathrm{O}_{2}\right)_{\mathrm{ads}} \rightleftharpoons\left(\mathrm{O}_{2}^{-}\right)_{\mathrm{ads}} \rightleftharpoons 2\left(\mathrm{O}^{2-}\right)_{\text {ads }} \rightleftharpoons 2\left(\mathrm{O}^{2-}\right)_{\mathrm{ox}}
$$

しだいに $E, C, D$ が主化学種となる。ただし，前述 したように $B \sim E$ には $\mathrm{Cs}, \operatorname{Re}$ の酸素物酸素の O $1 \mathrm{~s}$ が 重複しているので各コアスペクトルの挙動はきわめて複 雑となっている。一方, UHV 下での室温から $210^{\circ} \mathrm{C} \nearrow$
】への昇温時には，乙の平衡は右から左へ移動し， $E$ は まったく存在していない。

\section{5 降温表面亡 $133 \mathrm{~Pa}-\mathrm{O}_{2}$ 暴露表面}

110 分間の $\mathrm{O}_{2}$-Jet 作動後室温まで降温すると $\mathrm{Re}^{6+}$ 
は $\mathrm{Re}^{7+}$ に酸化され, $\mathrm{Re}_{2} \mathrm{O}_{7}$ の Ols $(531.5 \sim 9 \mathrm{eV})$ と 重なる分子吸着種 $B$ の増大とサブサーフェス酸素 $C$ と 吸着酸素原子 $D$ の減少が起り, 酸化物酸素 $E$ の比率 はむしろ増加したこと (Fig. 4) などから, $\mathrm{CsReO}_{4}$ の 複合酸化物の生成が起きている ( $\mathrm{Cs}$ の大部分は $\mathrm{Cs}_{2} \mathrm{O}$ ) と思われる。しかし，乙の降温によって Cs, Re, 抢よび ○の表面濃度はほぼ半減している。乙れは加熱時には表 面に pile-up していた Ag 以外の元素のバルク内への “潜りてみ (creep-in)”によるあのである。さらに 133 $\mathrm{Pa}-\mathrm{O}_{2}$ 暴露後は $\mathrm{Cs}$ と全酸素量は 1.4 倍に, 分子吸着種 $B$ とサブサーフェス酸素が 2 倍に増加している。Re $4 \mathrm{f}_{7 / 2}$ は変わらず, Cs $3 \mathrm{~d}_{5 / 2}$ は酸化側にシフトし, 酸化物酸素 $E$ は完全に失われている。 $\mathrm{CsO}_{2}$ の $\mathrm{O} 1 \mathrm{~s}$ は $530.1 \mathrm{eV}$ であり, Ayoob と Hedge は高被覆率 Cs/Ag-matel 上 への酸素吸着において $\mathrm{O} / \mathrm{Cs}=3(533 \mathrm{eV})$ を得ている5)。 Campbell は $\mathrm{Ag}$ (111) 上への $\mathrm{Cs}$ と $\mathrm{O}_{2}$ の共吸着時の LEED 構造から $\mathrm{CsO}_{3}$ の生成を報告している ${ }^{13)}$ 。乙 れらのととから，添加元素は主として $\mathrm{CsO}_{x}(x \geqq 2)$ と $\mathrm{Re}_{2} \mathrm{O}_{7}$ の形態で存在しているすのと考えられる。

\section{6 まとめ}

XPS を用いて表面の化学状態の変化を知ることは, 固体表面の特性とその安定性, および各種表面分析装置 で得られる情報の正確な評価, 解釈に寄与する。本研究 で用いた $(\mathrm{Cs}+\mathrm{Re})$ 添加 $\mathrm{Ag}$ 試料は表面状態, 添加元素 の濃度および表面酸素種の組成がきわめて変動しやすい あのの一つであるが，加温および $\mathrm{O}_{2}$-Jet 作動による楞 動に対応した XPS スペクトルの応答が鮮明かつダイナ ミックに in situ 観測できた。得られた情報から, 表面 で起きている複雑な化学的変化の定量的に十分な説明は できなかったが，同表面上で起こる示唆に富んだ化学的 現象を見出すことができた。具体的には，

（1） 加熱による $\operatorname{Re}^{7+}$ から $\operatorname{Re}^{0}$ への還元と $\mathrm{Cs}, \mathrm{Re}$ の pile-up 現象,

（2） $210^{\circ} \mathrm{C}$ での $\mathrm{O}_{2}$-Jet 作動中に起こる $\mathrm{Re}^{0}$ から $\mathrm{Re}^{6+}$ への酸化, 表面酸素種の動的組成变化, お よび $\mathrm{C}_{2} \mathrm{O}$ と $\mathrm{Cs}_{2} \mathrm{ReO}_{4}$ の生成,

（3） $210^{\circ} \mathrm{C}$ から室温への降温時の Cs, Re, O のバル ク内部への拡散移動,

（4）過度の酸化による $\mathrm{Cs}_{2} \mathrm{O}$ の消失 などが同一試料でかつ連続的に観察され，きわめて特徽 のある情報が得られた。てれらすべての現象は再現性良 く得られているととあ付記しておく。

少なくとも $10^{-7} \mathrm{~Pa}$ 以下の真空下で使用されるべき XPS 装置内で $10^{-6} \mathrm{~Pa}$ 台の $\mathrm{O}_{2}$ ガス導入は一見乱暴 に見えるが，光電子の飛行はそれほど阻害されていな い(Fig. 5)。しかも, 本研究での定量的解析は相対值

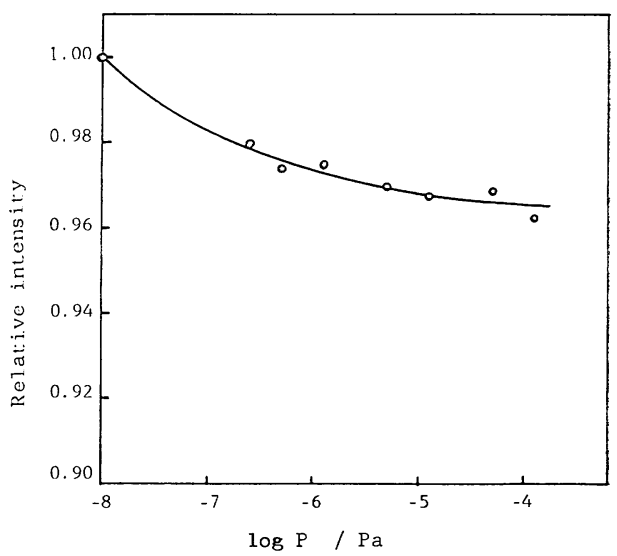

Fig. 5 Dependence of Ag $3 \mathrm{~d}_{5 / 2}$ integral intensity on Ar pressure in analysis chamber (sample is silver plate).

（atom\%）で評価しているので，真空圧の影響はほとん ど含まれていないと考えられる。との $\mathrm{O}_{2}$-Jet 法を用い たXPS 測定法は表面あるいはドープ元素または不純物 元素の酸化還元挙動の测定と解析一特に触媒などの活性 表面の解析一に有効であると考えられる。

\section{文献}

1) Sell Intern. Res. Maatschappij B. V., 特開昭 63-126552; EP-0352849 A 1; EP-032850 A 1.

2) J.E. Moulder, W.F. Stickle, P.E. Sohol and K. D. Bomben : "Handbook of X-ray Photoelectron Spectroscopy" (Perkin-Elmer Co., 1992).

3）D. Briggs and M.P. Seah : “表面分析一基礎と 応用一上巻”（合志陽一，志水隆一監訳，アグネ 承風社, 1990) p. 267.

4）鈴木英之, 菖蒲明己：日化，1992，(No. 9), p. 930.

5) M. Ayyoob, M. S. Hegde, Surf. Sci. 133, 516 (1983).

6) 大木道則, 大沢利昭, 田中元治, 千原秀昭編 : “化学大辞典” (東京化学同人, 1989) p. 886.

7) G. J. Leigh and W. Bremser: J. Chem. Soc. (Dolton) 1217 (1972).

8) L.E. Cox and D. M. Hercules: J. Electron Spectr. 1, 197 (1972).

9) E. S. Shpiro, V.I. Avaev, G. V. Antoshin, M. A. Ryashentseva and Kh. M. Minachev. : J. Catal. 55, 402 (1978).

10) A. Cimino, B. A. De Angelis, D. Gazzoli and M. Valigi: Z. Anorg. Allg. Chem. 460, 86 (1980).

11) M. Komiyama, Y. Ogino, Y. Akai and M. Goto: J. Chem. Soc. Faraday Trans. (-2) 79, 1719 (1983).

12）三浦裕幸, 菖蒲明己, 加納久雄, 宮原孝四郎, 豊 嶋勇 : 真空 25, 302 (1982).

13) Ch. T. Campbell : J. Phys. Chem. 89, 5789 (1985). 